\title{
NEW RECORDS OF MOTHS ELUCIDATE THE IMPORTANCE OF FORESTS AS BIODIVERSITY HOT-SPOTS IN CENTRAL MEDITERRANEAN LANDSCAPES (LEPIDOPTERA)
}

\author{
(*) Consiglio per la ricerca in agricoltura e l'analisi dell'economia agraria, centro di ricerca Foreste e Legno (CREA- \\ FL), Rende, Italy \\ (**) Via Castelvetere 40, 89041 Caulonia, Reggio Calabria, Italy \\ $\left({ }^{\circ}\right)$ Corresponding author: silvia.greco@crea.gov.it
}

Greco S., Ienco A., Infusino M., Leonetti F.L., Scalercio S. - New records of moths elucidate the importance of forests as biodiversity hot-spots in central Mediterranean landscapes (Lepidoptera).

In this paper we report new faunistic findings concerning 15 moth species collected in forested habitats of Calabria and Sicily regions, South Italy. Most interesting records concerned Eupithecia trisignaria and Orectis proboscidata, both recorded for the first time in southern Italy. Species with larval biology linked to the forest cover were locally common, whilst species linked to herbaceous plants and shrubs were often collected as singletons or in one locality, showing smaller populations. A study of a $658 \mathrm{bp}$ long sequence of the mitochondrial 5' cytochrome oxidase gene, subunit 1 (COI) (barcoding analysis) was performed for five species, two of them showing a divergence from closest populations near to $1 \%$, one a $2 \%$ divergence from northern populations, and two other species a perfect identity with European populations. This study reinforced the role of forest habitats as biodiversity hot-spots in the Mediterranean Basin and the importance of the Italian peninsula for biodiversity conservation at European scale as an increased number of endemic or sub-endemic taxa and populations with endemic genetic lineages are recognized, underlining the existence of ongoing evolutionary processes. In the light of these results, faunistic surveys in forest ecosystems are strongly needed to define sustainable management strategies.

KEY WORDS: barcoding, faunistic inventories, forest management, protected areas, Italy.

\section{INTRODUCTION}

Ecological sustainability of forests is nowadays one of the main goal of silvicultural management, as they provide several ecosystem services among which biodiversity conservation is increasingly emphasized (LINDENMAYER et al., 2000). Forests represent the climax stage of vegetation for the largest portion of Italian peninsula, but human activities largely fragmented their cover for thousands of years, increasing the proportion of non-forested habitats. Recently, human activities in interior areas were abandoned and, as a consequence, forested surfaces increased on large territories with consequences on biodiversity (MARULL et al., 2015) and on the economic profitability due to an increased wood availability. Then, it is very important in this phase to take into account both conservation and economic interests in order to identify areas with different vocations and to favour a sustainable management of forests. Timber production is nowadays mostly concentrated within mountain forests, particularly vulnerable ecosystems as the increasing frequency of extreme climatic events due to climatic changes can strongly affect tree physiology (KRAMER et al., 2000; LinDNER et al., 2010). Furthermore, recent studies underlined the importance of Mediterranean forest as biodiversity reservoirs (WALENTOWSKI et al., 2014; INFUSINO et al., 2016; 2017a), but how really important they are is not clear enough as several forest types and their latitudinal variations are not systematically investigated. Under these perspectives, biodiversity inventories become a basic data for identifying areas with a prominent conservation interest and areas that can be designed primarily for timber production.

Indicator taxa are useful tools for exploring biodiversity patterns saving time and money. Among them, the order of Lepidoptera was often used as a bioindicator of forested habitats as it represents a large portion of the total animal biomass and diversity, occupying many crucial ecological niches (SUMMERVILLE et al., 2004; SUMMERVILLE and CRIST, 2008). In Italy, biodiversity inventories for Lepidoptera are now available for several areas of conservation interest, e.g. the Parco Naturale delle Capanne di Marcarolo in Piedmont (BAldizzone et al., 2013), the Tenuta Presidenziale di Castelporziano in Latium (ZILLI et al., 2001), the silver fir forest of Rosello between Abruzzi and Molise regions (SCIARRETTA and ZAHM, 2002), the silver fir forest of Serra San Bruno and the Vivaio Sbanditi and in Calabria (INFUSINO and SCALERCIO, 2017; INFUSINO et al., 2017b) and many more (see ZILLI, 2014; 2018). Unfortunately, methods and sampling efforts were usually not comparable across studies and only in few cases exact locations of sampled sites were provided, making it difficult to compare quantitative results and to repeat the monitoring over time. Nevertheless, faunistic lists provided by these inventories were enough to demonstrate that Mediterranean forests, especially mountain ones, are particularly important from a conservation point of view as they represent very important biodiversity hot-spots for Lepidoptera, inhabiting endemic species, relict populations of Euro-Asiatic species, populations with unique genetic lineages (SCALERCIO et al., 2016; INFUSINO et al., 2016, 2018). 
This paper would be a further contribution toward a better understanding of the role of forest ecosystems as biodiversity reservoirs. We reported the presence of species with high biogeographic and conservation interest noted during surveys carried out systematically in mountain forests and occasionally in other habitats of Calabria and Sicily, the southernmost Italian regions positioned in the middle of the Mediterranean Basin. The presence of these species was discussed from biogeographic and conservation perspectives, and the importance of a sustainable forest management was also underlined.

\section{MATERIAL AND METHODS}

Results showed in this paper were collected from systematic and occasional surveys of moths in different forested habitat of Calabrian region, southern Italy.

Systematic surveys were devoted to characterize moth community of a given forest type in order to assess functional relationships of forest attributes, such as tree species composition, management, age, with moth diversity and abundance. This kind of survey was carried out by the authors in several forest type during last years (GRECO et al., 2016; Infusino et al., 2016; 2017a). In this paper we synthesized the most interesting biogeographic results obtained during the last year of monitoring within beech forests and Acer-dominated forests included in the Pollino National Park, Calabrian black pine forests and Alnusdominated woodlots included in the Sila National Park, and mixed forests of both protected areas. Samplings were carried out using UV LED light traps (INFUSINO et al., 2017c) powered by portable batteries. Traps were settled up one night per month through the entire flight season of moth at mountain altitude, under weather conditions favourable to moth activity and trap efficiency, i.e. low wind speed, temperatures near the average of a given period, low or absent moonlight, low or absent rain.

Occasional surveys interested Calabria and Sicily regions. In Calabria we surveyed a clearing within broadleaved forests in the Pollino National Park by diurnal visual census and a sparse Mediterranean maquis along the Ionian coast using a $160 \mathrm{~W}$ mercury vapor lamp as light source for a moth trap. In Sicily we surveyed a Taxus baccata-dominated forest on the Nebrodi Mountains using a 160W mercury vapor lamp reflecting on a white sheet for attracting moth.

Detailed data concerning sites and nights of both kind of surveys were reported in the List of species section.

Identification was carried out using specialised literature concerning Lasiocampidae (BERTACCINI et al., 1995), Geometridae (Hausmann, 2001, 2004; Mironov, 2003; HAUSMANN and ViIDALEPP, 2012), Erebidae (BERIO, 1991; BERTACCINI et al., 1995, 1997), and Noctuidae (BERIO, 1985). Identification of most difficult species was carried out after dissection of genitalia. Nomenclature followed the Fauna Europaea available online at www.faunaeur.org. Specimens and slides of genitalia were preserved in the Lepidoptera collection of the Research Centre for Forestry and Wood, Rende, Italy.

Few specimens were submitted to barcoding, an analysis of the $658 \mathrm{bp}$ long sequence of the mitochondrial 5 , cytochrome oxidase gene, subunit 1 (COI), submitting tissue samples to the standard procedures of the Canadian Centre for DNA Barcoding (CCDB). This sequence, considered a standard marker for species identification of most animals, allowed us to search for genetic divergences of southern Italy population of analysed species from other
European populations, by comparing sequences deposited in the database of Barcoding of Life Database (BOLD) data systems (RATnASIngham and HeBert, 2007). For any barcoded specimen we reported the following genetic data: BOLD specimen ID, BOLD sequence ID, Barcode Index Number (BIN), sequence length, genetic similarity with the nearest sequence deposited in BOLD and its collecting site.

\section{RESULTS}

A total of 15 species of biogeographic interest has been collected during our study: seven Geometridae, one Lasiocampidae, three Erebidae, four Noctuidae (Fig. I). Among them, eight species were collected as singletons and further two in only one locality, whilst the others were collected in more than one locality. The Acer-dominated forest provided nine species new for the Calabria region, whilst beech, Calabrian black pine, Alnus glutinosa, Taxus baccata, and mixed forests provided one species each new for the regional fauna. Remaining species were collected in a clearing within broadleaved forests and in a sparse Mediterranean maquis.

Five specimens belonging to five species were submitted to DNA barcoding analyses, recovering four full-length sequences (658bp) and a somewhat shorter one (630bp).

\section{LIST OF SPECIES}

Poecilocampa populi (Linnaeus, 1758) (Lasiocampidae) (Fig. I, 1)

Habitat - Beech forest of the Pollino National Park.

RECORDS - Serrapaolo, Saracena (CS), 990m, $39.8225^{\circ} \mathrm{N}-$ 16.0911 ${ }^{\circ} \mathrm{E}, 18 . X I .2015(1 \mathrm{~m})$ (dissected, slide CREA-0182, Fig. II, 1); Serra Ambruna, Saracena (CS), 1035m, 39.8234 ${ }^{\circ} \mathrm{N}-16.0768^{\circ} \mathrm{E}, 23$. XI.2017 (1m); Timpone Magara, Saracena (CS), $1460 \mathrm{~m}, 39.7914^{\circ} \mathrm{N}-16.0503^{\circ} \mathrm{E}, 23 . \mathrm{XI} .2017$ (1f); idem, $1465 \mathrm{~m}, 39.7939^{\circ} \mathrm{N}-16.0520^{\circ} \mathrm{E}, 23 . X I .2017$ (1f).

Alsophila aceraria (Denis \& Schiffermüller, 1775) (Geometridae) (Fig. I, 2)

HABITAT - Calabrian black pine forest of the Sila National Park.

ReCords - Serra Cannile, Spezzano Sila (CS), 1433m, $39.3465^{\circ} \mathrm{N}-16.4091^{\circ} \mathrm{E}, 24 . \mathrm{XI} .2017$ (1m).

Emmiltis pygmaearia (Hübner, 1809) (Geometridae) (Fig. I, 3)

HABITAT - Clearings in broadleaved forests of the Pollino National Park.

ReCORDS - Timpone Montillo, Alessandria del Carretto (CS), $960 \mathrm{~m}, 39.9578^{\circ} \mathrm{N}-16.3754^{\circ} \mathrm{E}, 19 . \mathrm{V} .2017$ (1m, 1f).

Cyclophora albiocellaria (Hübner, 1789) (Geometridae) (Fig. I, 4)

HABITAT - Acer forest of the Pollino National Park.

Records - Balestrieri, Alessandria del Carretto (CS), $1371 \mathrm{~m}, \quad 39.9275^{\circ} \mathrm{N}-16.3624^{\circ} \mathrm{E}, 21 . V I .2017$ (1m), 17.VIII.2017 (1f); Difesa di Privitera, Alessandria del 


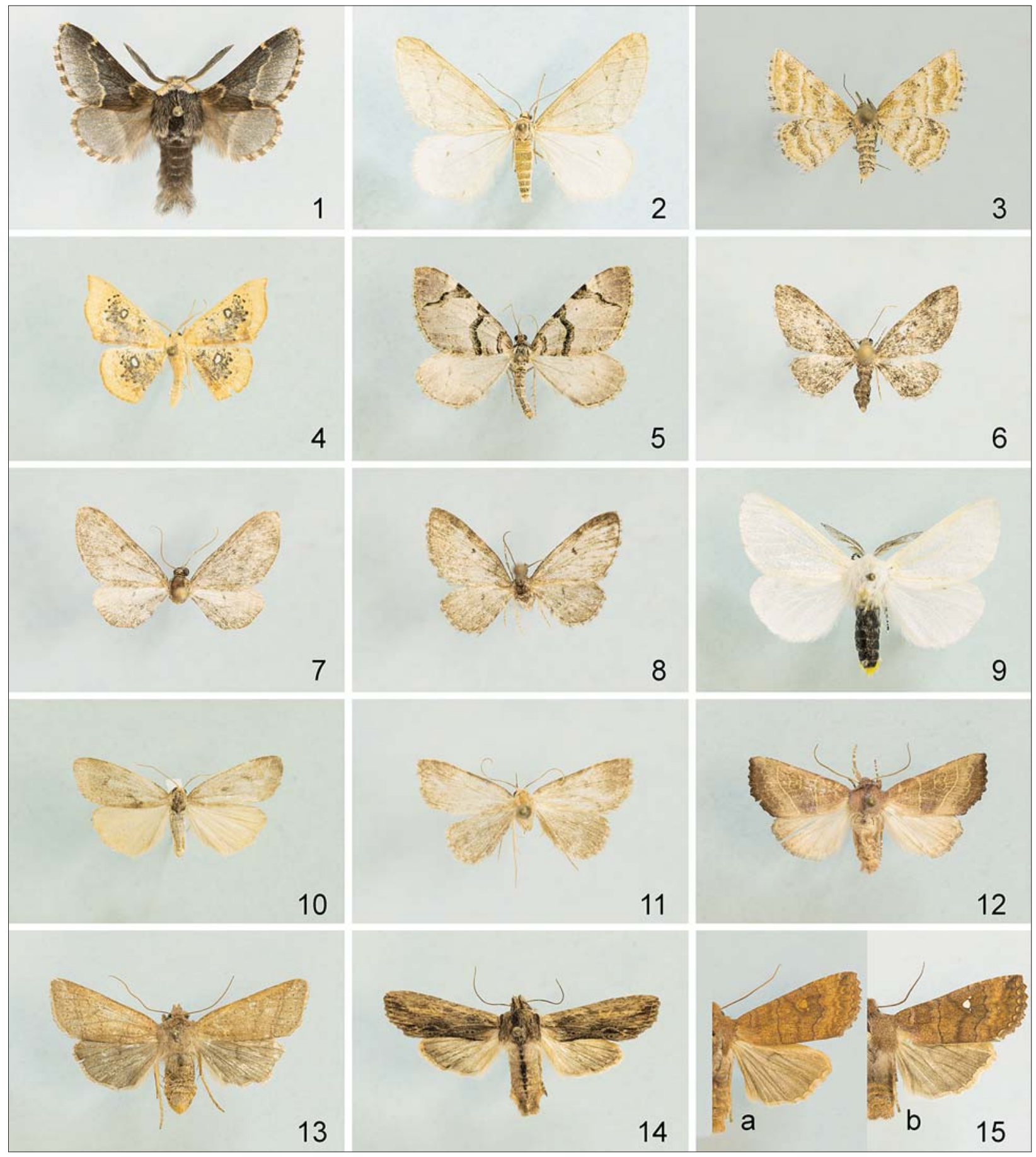

Fig. I - Habitus of species: Poecilocampa populi (Linnaeus, 1758), Serra Ambruna (1); Alsophila aceraria (Denis \& Schiffermüller, 1775), Serra Cannile (2); Emmiltis pygmaearia (Hübner, 1809), Timpone Montillo (3); Cyclophora albiocellaria (Hübner, 1789), Sciortaglie (4); Anticlea derivata (Denis \& Schiffermüller, 1775), Sciortaglie (5); Eupithecia inturbata (Hübner, 1817), Difesa di Privitera (6); Eupithecia denotata (Hübner, 1813), Vallone Lupara (7); Eupithecia trisignaria Herrich-Schäffer, 1848, Epicate (8); Leucoma salicis (Linnaeus, 1758), Sciortaglie (9); Apaidia rufeola (Rambur, 1832), Palizzi Marina (10); Orectis proboscidata (Herrich-Schäffer, 1851), Vallone Lupara (11); Atethmia ambusta (Denis \& Schiffermüller, 1775), Difesa di Privitera (12); Agrochola orejoni Agenjo, 1951, Balestrieri (13); Lithophane semibrunnea (Haworth, 1809), Sciortaglie (14); Eupsilia transversa (Hufnagel, 1766), Bosco della Tassita (15a), Balestrieri (15b).

Carretto (CS), $1314 \mathrm{~m}, 39.9269^{\circ} \mathrm{N}-16.3563^{\circ} \mathrm{E}, 17 . \mathrm{VIII} .2017$ (2m); idem, $1285 \mathrm{~m}, 39.9274^{\circ} \mathrm{N}-16.3572^{\circ} \mathrm{E}, 17 . \mathrm{VIII} .2017$ (1m); Sciortaglie, Alessandria del Carretto (CS), 1253m, $39.9291^{\circ} \mathrm{N}-16.3532^{\circ} \mathrm{E}, 17$. VIII.2017 (1m, 1f); idem, $1246 \mathrm{~m}, 39.9313^{\circ} \mathrm{N}-16.3508^{\circ} \mathrm{E}, 17$. VIII.2017 (1m, 2f); Tappaiolo, Alessandria del Carretto (CS), $1253 \mathrm{~m}$, $39.9358^{\circ} \mathrm{N}-16.3471^{\circ} \mathrm{E}, 17$. VIII.2017 (1m).
Anticlea derivata (Denis \& Schiffermüller, 1775) (Geometridae) (Fig. I, 5)

HABITAT - Acer forest of the Pollino National Park.

RECORDS - Sciortaglie, Alessandria del Carretto (CS), $1246 \mathrm{~m}, 39.9313^{\circ} \mathrm{N}-16.3508^{\circ} \mathrm{E}, 18 . \mathrm{IV} .2017$ (1m). 


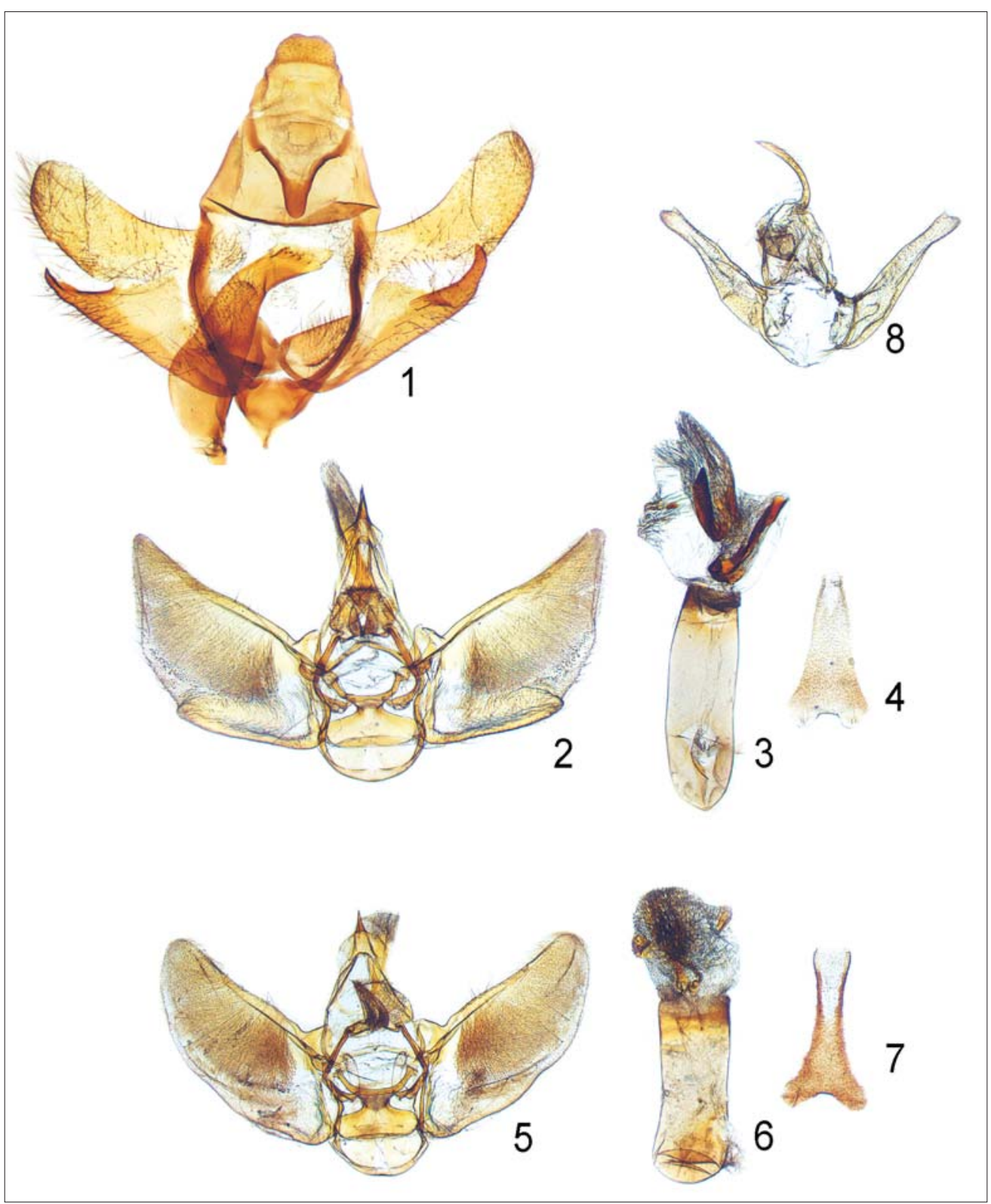

Fig. II - Male genitalia: (1) Poecilocampa populi (Linnaeus, 1758), slide CREA-0182; (2) Eupithecia denotata (Hübner, 1813) with (3) phallus and (4) sternum A8, slide CREA-0201; (5) Eupithecia trisignaria HerrichSchäffer, 1848 with (6) phallus and (7) sternum A8, slide CREA-0190; (8) Orectis proboscidata (HerrichSchäffer, 1851), slide CREA-0174.

GENETIC DATA - LEP-SS-00607, BCLEP157-17, BOLD:AAD2706, 658bp, 99.08\% of similarity with a specimen collected in Bavaria, Germany.

\section{Eupithecia inturbata (Hübner, 1817) (Geometridae)} (Fig. I, 6)

HABITAT - Acer forest of the Pollino National Park.

RECORDS - Vallone Lupara, Alessandria del Carretto (CS), $1305 \mathrm{~m}, 39.9259^{\circ} \mathrm{N}-16.3603^{\circ} \mathrm{E}, 19 . \mathrm{VII} .2017$ (2f) (1 dissected); Difesa di Privitera, Alessandria del Carretto (CS), $1285 \mathrm{~m}$, $39.9274^{\circ} \mathrm{N}-16.3572^{\circ} \mathrm{E}, 19 . \mathrm{VII} .2017$ (1m, 2f) (1 barcoded); idem, $1291 \mathrm{~m}, 39.9274^{\circ} \mathrm{N}-16.3572^{\circ} \mathrm{E}, 17 . \mathrm{VIII} .2017$ (1f) (dissected); Sciortaglie, Alessandria del Carretto (CS), 1253m, $39.9291^{\circ} \mathrm{N}-16.3532^{\circ} \mathrm{E}, 17 . \mathrm{VIII} .2017$ (2f) (1 dissected); idem, $1246 \mathrm{~m}, 39.9313^{\circ} \mathrm{N}-16.3508^{\circ} \mathrm{E}, 18 . \mathrm{IX} .2017$ (1f) (dissected).

GENETIC DATA - LEP-SS-00667, BCLEP217-17, BOLD: AAB89169, 630bp, $99.68 \%$ of similarity with a specimen collected in Carinthia, Austria.

\section{Eupithecia denotata (Hübner, 1813) (Geometridae) (Fig. I, 7)}

HABITAT - Acer forest of the Pollino National Park.

ReCORDS - Vallone Lupara, Alessandria del Carretto (CS), $1305 \mathrm{~m}, 39.9259^{\circ} \mathrm{N}-16.3603^{\circ} \mathrm{E}, 19$. VII.2017 (1m) (dissected, slide CREA-0201, Fig. II, 2). 
Eupithecia trisignaria Herrich-Schäffer, 1848

(Geometridae) (Fig. I, 8)

Habitat - Alnus glutinosa forest of the Sila National Park.

RECORDS - Epicate, San Giovanni in Fiore (CS), 1250m, $39.3349^{\circ} \mathrm{N}-16.6146^{\circ} \mathrm{E}, 28 . \mathrm{VI} .2017$ (3m) (3 dissected, 1 slide CREA-0190, Fig. II, 3).

\section{Leucoma salicis (Linnaeus, 1758) (Erebidae)}

(Fig. I, 9)

HABITAT - Mixed forests of Pollino and Sila National Parks.

RECORDS - Sciortaglie, Alessandria del Carretto (CS), $1253 \mathrm{~m}, 39.9291^{\circ} \mathrm{N}-16.3532^{\circ} \mathrm{E}, 21$. VI.2017 (1m); Lago Cecita, Spezzano della Sila (CS), $1176 \mathrm{~m}, 39.3864^{\circ} \mathrm{N}-$ $16.5516^{\circ} \mathrm{E}, 30 . \mathrm{VII} .2013$ (1 m); Montagna Grande, San Giovanni in Fiore (CS), $1355 \mathrm{~m}, 39.2717^{\circ} \mathrm{N}-16.6062^{\circ} \mathrm{E}$, 5.VII.2016 (1m)

Apaidia rufeola (Rambur, 1832) (Erebidae) (Fig. I, 10)

HABITAT - Sparse Mediterranean maquis.

RECords - Palizzi Marina (RC), 3m, $37.9193^{\circ} \mathrm{N}$ $16.006^{\circ} \mathrm{E}, 15 . \mathrm{V} .2015(1 \mathrm{~m})$

\section{Orectis proboscidata (Herrich-Schäffer, 1851) (Erebidae)} (Fig. I, 11)

HABITAT - Acer forest of the Pollino National Park.

ReCORds - Vallone Lupara, Alessandria del Carretto (CS), $1345 \mathrm{~m}, 39.9245^{\circ} \mathrm{N}-16.3609^{\circ} \mathrm{E}, 17$. VIII.2017 (1m) (dissected, slide CREA-0174, Fig. II, 4).

GENETIC DATA - LEP-SS-00720, BCLEP267-17, BOLD: AAP3890, 658bp, $99.05 \%$ of similarity with a specimen collected in Sicily, Italy.

Atethmia ambusta (Denis \& Schiffermüller, 1775) (Noctuidae) (Fig. I, 12)

HABITAT - Acer forest of the Pollino National Park.

ReCords - Difesa di Privitera, Alessandria del Carretto (CS), $1285 \mathrm{~m}, 39.9274^{\circ} \mathrm{N}-16.3572^{\circ} \mathrm{E}, 17$. VIII.2017 (1m).

Agrochola orejoni Agenjo, 1951 (Noctuidae) (Fig. I, 13)

Habitat - Acer forest of the Pollino National Park.

RECORDS - Balestrieri, Alessandria del Carretto (CS), $1371 \mathrm{~m}, 39.9275^{\circ} \mathrm{N}-16.3624^{\circ} \mathrm{E}, 12 . X I .2017$ (1f).

Lithophane semibrunnea (Haworth, 1809) (Noctuidae) (Fig. I, 14)

HaBitat - Acer forest of the Pollino National Park.
RECORDS - Sciortaglie, Alessandria del Carretto (CS), $1253 \mathrm{~m}, 39.9291^{\circ} \mathrm{N}-16.3532^{\circ} \mathrm{E}, 17$. VIII.2017 (1m)

GENETIC DATA - LEP-SS-00645, BCLEP195-17, BOLD: AAJ2393, 658bp, $100 \%$ of similarity with specimens collected in several European countries.

\section{Eupsilia transversa (Hufnagel, 1766) (Noctuidae)}

(Fig. I, 15a, b)

Habitat - Acer forest of the Pollino National Park and Taxus baccata forest of the Nebrodi Mountains.

RECORDS - Balestrieri, Alessandria del Carretto (CS), $1371 \mathrm{~m}, 39.9275^{\circ} \mathrm{N}-16.3624^{\circ} \mathrm{E}, 12 . \mathrm{X} .2017$ (1f); Vallone Lupara, Alessandria del Carretto (CS), $1305 \mathrm{~m}, 39.9259^{\circ} \mathrm{N}$ $16.3603^{\circ} \mathrm{E}, 18 . \mathrm{IX} .2017$ (1f); Difesa di Privitera, Alessandria del Carretto (CS), $1285 \mathrm{~m}, 39.9274^{\circ} \mathrm{N}-16.3572^{\circ} \mathrm{E}$, 23.III.2017 (1m) (barcoded); Tappaiolo, Alessandria del Carretto (CS), $1253 \mathrm{~m}, 39.9358^{\circ} \mathrm{N}-16.3471^{\circ} \mathrm{E}, 18 . \mathrm{IX} .2017$ (1f); Bosco della Tassita, Caronia (ME), $1430 \mathrm{~m}, 37.90^{\circ} \mathrm{N}-$ $14.50^{\circ} \mathrm{E}, 13 . \mathrm{X} .2009$ (3f)

GENETIC DATA - LEP-SS-00629, BCLEP179-17, BOLD: AAC 7414, 658bp, $100 \%$ of similarity with specimens collected in several European countries.

\section{DISCUSSION}

In this paper we report 15 new records of species that significantly enlarged their known range or confirmed their presence in southern Italy, elucidating the role of Mediterranean forests as biodiversity hot-spots.

\section{SPECIES PERSPECTIVES}

Most interesting findings certainly concerned the EuroSiberian Eupithecia trisignaria and the South-East EuroAnatolian Orectis proboscidata which had never found before in southern Italy.

Eupithecia trisignaria is widespread in Central and Northern Europe, with scattered populations towards the south. In Italy it is known from the Alps and for very few localities in the northern and central Apennines (PARENZAN and PorCelli, 2007). The nearest known population to those found in the Sila Massif is about $370 \mathrm{~km}$ northward, at 1250 metres of altitude but authors did not provide any habitat description (FLAMIGNI et al., 2002). Recently, the moth fauna of Sila Massif was intensively investigated (SCALERCIO et al., 2008; INFUSINO et al., 2016; 2017a,b), but this species was never found before. This is probably due to the small population size, likely being restricted in its local range to the optimal habitat, here represented by a humid forest of Alnus glutinosa.

Orectis proboscidata has isolated populations in his range, found in Italy in the Alps, in one locality from central Apennines about one century ago (DANNEHL, 1927), and in a few Sicilian localities (Bella and Fibiger, 2009). The specimen we found is particularly important as it could reopen a question about the taxonomy of southernmost Italian populations. TURATI (1908) described Orectis barteli from Sicily, successively synonymized under $O$. proboscidata (ZILLI, 1996). Based on DNA barcoding analysis, Sicilian and Calabrian populations show a genetic divergence of about $2 \%$ from Alpine and Balcanic populations, suggesting the need of further investigation on the taxonomy of southern Italian populations (Fig. III). 


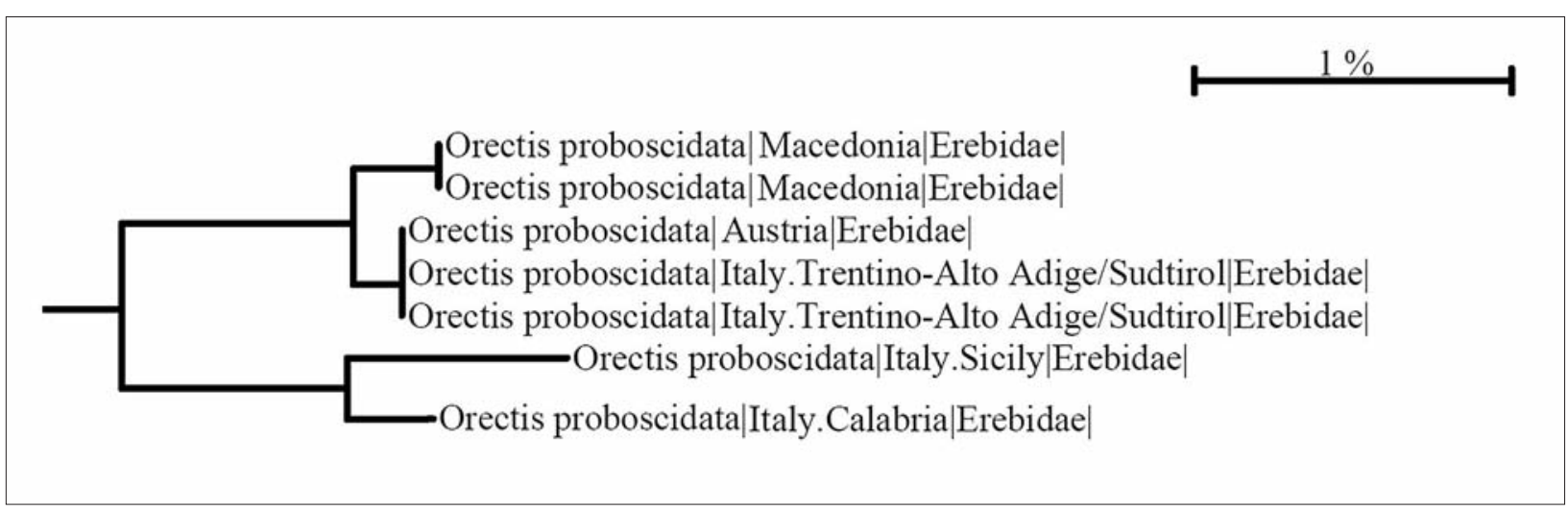

Fig. III - Neighbor joining trees (Kimura 2-parameter distance model for COI-5P marker) of European Orectis proboscidata specimens built using sequences deposited in BOLD.

Very interesting was also the second finding of Agrochola orejoni in Italy, a species having a very disjunct range being present in Spain and in the Pollino Massif, Italy, where an endemic subspecies was described by PARENZAN (1982a), $A$. orejoni terranovae.

Other species represent new findings for the Calabrian region and Eupsilia transversa was new also from Sicily, all enlarging their range southward. Alsophila aceraria was erroneously reported from Calabria by FLAMIGNi et al. (2001), as FLAMIGNI and BASTIA (2003) clarified that it was a mistake in data transcription. Our data confirmed its presence in Calabria, where it was found in the Sila Massif. Lithophane semibrunnea was also recorded from Calabria in a previous paper (INFUSINO et al., 2017a), but it was due to a misidentification as the used reference literature (BERIO, 1985) shows vice-versa exchanged images for L. semibrunnea and L. socia. Our record is the first correctly attributed to L. semibrunnea in this region. Although Poecilocampa populi is known from the Pollino Massif since more than three decades (PARENZAN, 1982b), our finding in new localities of the same massif confirmed its presence with a population about $400 \mathrm{~km}$ apart from the nearest.

As discussed above, DNA barcoding analysis identified the population of $O$. proboscidata as the most diverging from Central and South-Eastern European populations. Other barcoded specimens showed a COI divergence varying from $0.92 \%$ for $A$. derivata to 0 for $L$. semibrunnea and Calabrian $E$. transversa, whilst $E$. inturbata diverged by $0.32 \%$. We can hypothesize a more recent colonization of the Pollino Massif for less divergent species, and likely a longer isolation history for the most divergent.

\section{HABITAT PERSPECTIVES}

Systematic surveys carried out in the Acer-dominated forest provided most of the new records discussed in this paper. The main factor determining the relevance of this forest type was the lack of previous surveys in this peculiar forest, characterizing the Site of Community Importance IT9310019 Monte Sparviere, Pollino National Park. Five species of Acer are present in this forest (ROMA-MARZIO et al., 2016), thanks mainly to the local microclimate, soil and geomorphology. These factors favor the presence of wellestablished populations of Cyclophora albiocellaria and Eupithecia inturbata, species having monophagous larvae on this tree genus (MIrONOV, 2003; HAUSMANN, 2004). The establishment of these populations is attributable not only to the presence of hostplants but also to the microclimatic conditions which characterize this area and to the bio- geographic history of the Pollino Massif. In addition to the two above mentioned, most species found in this habitat have larvae feeding on deciduous trees, namely Eupsilia transversa, Atethmia ambusta, Lithophane semibrunnea, and Leucoma salicis, found also in mixed forests of the Sila Massif. Only Eupithecia denotata, oligophagous mainly on Campanulaceae, and Orectis proboscidata, with larvae feeding on vegetal detritus, are not linked to trees for their larval development. Agrochola orejoni is known to be a forest species, but larval biology is unknown.

Other species linked to deciduous trees found in systematic surveys were Poecilocampa populi, found in a beech forest, and Alsophila aceraria, found in a forest dominated by Calabrian black pine, whilst Eupithecia trisignaria, the only species of interest found in Alnus glutinosa woods, is oligophagous on Apiaceae (MIRONOV, 2003).

Finally, occasional findings were not strictly linked to forests, as Emmiltis pygmaearia inhabit xerothermophilous grasslands (HAUSMANN, 2004) and Apaidia rufeola coastal areas (BERTACCINI et al., 1995). Only the Sicilian finding of Eupsilia transversa is attributable to a woody plant feeder.

INFUSINO et al. (2016) found mid and late successional stages of forests more important than early successional stages of forests in sustaining lepidopteran diversity in managed mountain forests. This occurred also in the highly exploited chestnut forest, in which mature coppices inhabit many species of biogeographic and conservation interest. The results showed in this paper were consistent with those of INFUSINO et al. (2016), as they were mostly obtained in forests included in protected areas submitted to low perturbations. Nevertheless, some considerations concerning forest management can be carried out. In particular, the role of undergrowth flora is underlined by the presence of isolated populations of important species linked to this forest layer. The species composition related to the undergrowth is also determined by microclimatic conditions favored by forest cover. Most ecological-oriented management strategies should take into account the effect of changes in forest cover on diversity and composition of understory flora as a key factor for sustaining biodiversity.

\section{CONCLUSIONS}

In this paper we report new finding concerning 15 moth species that clearly elucidate the role of forest habitats as biodiversity hot-spots, especially in the Mediterranean Basin. Most records enlarged the known species ranges 
southward, in a very significantly manner for Eupithecia trisignaria. As underlined by recent papers, the importance of Italian peninsula for biodiversity conservation at European scale is strategic as an increased number of endemic or sub-endemic taxa are recognized (SCALERCIO et al., 2016; INFUSINO et al., 2018), most of which trophically linked to trees. Furthermore, some species show endemic genetic lineages in southern Italy (TREMATERRA et al., 2017; INFUSINO et al., 2017a), underlying the existence of ongoing evolutionary processes. In the light of these results, an extensive study of biodiversity hosted by forest ecosystems, accompanied by barcoding analyses, are strongly needed to define the biodiversity hosted within Mediterranean forest ecosystems in order to refine conservation strategies towards adequate management regimes.

\section{ACKNOWLEDGEMENTS}

The work was financially supported by the Pollino National Park (Project Studio pilota per il monitoraggio della biodiversità dei Lepidotteri in SIC forestali del Parco Nazionale del Pollino), the Sila National Park (Project Il Barcoding delle farfalle nel Parco Nazionale della Sila: aree umide), the University of Tuscia (Project REFORM SUMFOREST), the Project "ALForLab" (PON03PE 00024 1) co-funded by the National Operational Programme for Research and Competitiveness (PON R\&C) 2007-2013, through the European Regional Development Fund (ERDF) and national resource (Revolving Fund Cohesion Action Plan (CAP) MIUR).

\section{REFERENCES}

Baldizzone G., Cabella C., Fiori F., Varalda P. G., 2013 - I Lepidotteri del Parco Naturale di Marcarolo. Memorie dell'Associazione Naturalistica Piemontese, XII: 349 pp.

Bella S., Fibiger M., 2009 - Contribution to the knowledge of Noctuoidea in Sicily (Lepidoptera Nolidae, Erebidae, Noctuidae). - Il Naturalista Siciliano, IV Serie, XXXIII (1-2): 167-176.

BERIO E., 1985 - Lepidoptera Noctuidae. I. Generalità Hadeninae Cuculliinae. Fauna d'Italia, Vol. XXII, Ed. Calderini, Bologna, 970 pp., 32 tavv. col.

Berio E., 1991 - Lepidoptera Noctuidae. II. Sezione Quadrifide. Fauna d'Italia, Vol. XXVII, Ed. Calderini, Bologna, 708 pp., 16 tavv. col.

Bertaccini E., Fiumi G., Provera P., 1995 - Bombici e Sfingi d'Italia (Lepidoptera Heterocera). Volume I. Natura, Giuliano Russo Ed., Monterenzio (BO), 248 pp., 16 Tavv. col.

Bertaccini E., Fiumi G., Provera P., 1997 - Bombici e Sfingi d'Italia (Lepidoptera Heterocera). Volume II. Natura, Giuliano Russo Ed., Monterenzio (BO), 256 pp., 16 Tavv. col.

DANNEHL F., 1927 - Sammelreise nach Mittelitalien 1926 und ihre Ergebnisse. - Lepidopterologische Rundschau, 1: 11-12, 26-28, 35-37, 46-48.

Flamigni C., Bastia G., 2003 - Nuovi dati faunistici su alcune specie di Geometridi, Nottuidi e Nolidi dell'Italia centrale, meridionale e insulare (Insecta Lepidoptera Geometridae, Noctuidae, Nolidae). - Quaderno di Studi e Notizie di Storia Naturale della Romagna, 17 suppl.: 7986.

Flamigni C., Bastia G., Dapporto L., 2001 - Nuove segnalazioni e note critiche sui Geometridi di Emilia, Romagna e Toscana. I Parte (Insecta lepidoptera, Geometridae: Ennominae, Oenochrominae, Geometrinae, Sterrhinae). - Quaderno di Studi e Notizie di Storia Naturale della Romagna, 14: 89-112, 21 figg.

Flamigni C., Bastia G., Dapporto L., 2002 - Nuove segnalazioni e note critiche sui Geometridi di Emilia, Romagna e Toscana. II parte (Insecta Lepidoptera Geometridae: Larentiinae). - Quaderno di Studi e Notizie di Storia Naturale della Romagna, 16: 37-76, 38 figg.

Greco S., Infusino M., Bernardini V., Turco R., SCALERCIO S., 2016 - Timber vs. fruit production: partitioning of moth diversity within a mosaic-like chestnut forest. - Contemporary Engineering Sciences, 9 (28): 1387-1402.

Hausmann A., 2001 - Introduction. Archiearinae, Orthostixinae, Desmobathrinae, Alsophilinae, Geometrinae. In: A. Hausmann (ed.): The Geometrid Moths of Europe. Apollo Books, Stenstrup, Vol. 1: 282 pp., 7 col. pl., $41+41$ gen. figs., 229 Textfigs., maps.

HAUSMANN A., 2004 - Sterrhinae. In: A. Hausmann (ed.): The Geometrid Moths of Europe. Apollo Books, Stenstrup, Vol. 2: 600 pp., 24 col. pl., 196+196 gen. figs., 237 Textfigs., maps.

Hausmann A., Vildalepp J., 2012 - Larentiinae I (Perizomini and Eupitheciini). In: A. Hausmann (ed.): The Geometrid Moths of Europe. Vol. 3. Apollo Books, Stenstrup, 743 pp., 25 col. pl., 268+268 gen. figs., 147 Textfigs., maps.

Infusino M., Brehm G., Di Marco C., Scalercio S., 2017c. - Assessing the efficiency of UV LEDs as light sources for sampling the diversity of macro-moth. European Journal of Entomology, 114: 25-33.

Infusino M., Greco S., Turco R., Bernardini V., SCALERCIO S., 2016 - Managed mountain forests as diversity reservoirs in Mediterranean landscapes: new data on endemic species and faunistic novelties of moths. - Bulletin of Insectology, 69 (2): 249-258.

Infusino M., Hausmann A., Scalercio S., 2018 Ptilophora variabilis Hartig, 1968, bona species, and description of Ptilophora nebrodensis sp. $n$. from Sicily (Lepidoptera, Notodontidae). - Zootaxa, 4369 (2): 237 252.

INFUSINO M., LuZZI G., SCALERCIO S., 2017a - New insights on Lepidoptera of southern Italy with description of the male of Coenotephria antonii Hausmann 2011 (Lepidoptera). - Journal of Entomological and Acarological Research, 49 (6783): 89-96.

Infusino M., Luzzi G., Scalercio S., $2017 \mathrm{~b}-I$ macrolepidotteri notturni dell'Arboreto Sbanditi, Area MAB-UNESCO, Parco Nazionale della Sila (Calabria, Italia). - Memorie della Società Entomologica Italiana, 94 (1-2): 137-153.

INFUSINO M., SCALERCIO S., 2017 - The Macrolepidoptera Heterocera of silver fir woodlands in the Serre Mountains (Calabria, Southern Italy). In: A. Zilli (ed.), Lepidoptera Italica Vol. 2, Natura Edizioni Scientifiche, Bologna, Italy.

Kramer K., Leinonen I., Loustau D., 2000 - The importance of phenology for the evaluation of impact of climate change on growth of boreal, temperate and Mediterranean forests ecosystems: an overview. International Journal of Biometeorology, 44, 67-75.

LindenMaYer D.B., MARgules C.R., BotKIn D.B., 2000 Indicators of biodiversity for ecologically sustainable forest management. - Conservation biology, 14 (4): 941950. 
Lindner M., MaroscheK M., Netherer S., Kremer A., Barbati A., Garcia-Gonzalo J., Seidl R., Delzon S., Corona P., Kolström M., LeXer M.J., Marchetti M., 2010 - Climate change impacts, adaptive capacity, and vulnerability of European forest ecosystems. - Forest Ecology and Management, 259, 698-709.

Marull J., Otero I., Stefanescu C., Tello E., Miralles M., Coll F., Pons M., Diana G.L., 2015 - Exploring the links between forest transition and landscape changes in the Mediterranean. Does forest recovery really lead to better landscape quality? - Agroforestry Systems, 89:705-719.

Mironov L., 2003 - Larentiinae II (Perizomini and Eupitheciini). In: A. Hausmann (ed.): The Geometrid Moths of Europe. Vol. 4. Apollo Books, Stenstrup, 464 pp., 7 col. pl., 151+151 gen. figs., 87 Textfigs., maps.

PARENZAN P., 1982a - Segnalazione di alcune specie di Nottuidi nuove per la fauna italiana, e descrizione di due nuove sottospecie (Lepidoptera - Noctuidae). Entomologica, Bari, XVII: 127-147.

Parenzan P., 1982b - Bombyces e Sphinges (Lepid. Heterocera) dell'Italia meridionale (addenda). Entomologica, Bari, XVII: 103-125.

PARENZAN P., PORCElli F., 2007a - I macrolepidotteri italiani. Fauna Lepidopterorum Italiae (Macrolepidoptera). - Phytophaga, XV (2005-2006): 5-391.

Ratnasingham, S., Hebert, P.D.N., 2007 - BOLD: The Barcode of Life Data System (www.barcodinglife.org). Molecular Ecology Notes, 7: 355-364.

Roma-Marzio F., Bernardo L., Liguori P., Peruzzi L., 2016 - Vascular flora of Monte Sparviere (Southern Italy, Pollino Massif). - Atti della Società Toscana di Scienze Naturali, Memorie, Serie B, 122 (2015): 73-88.

Scalercio S., Infusino M., Hausmann A., 2016 Nothocasis rosariae $s p$. n., a new sylvicolous, montane species from southern Europe (Lepidoptera: Geometridae, Larentiinae). - Zootaxa, 4161 (2): 177-192.

Scalercio S., Infusino M., Tuscano J., 2008 - I macrolepidotteri notturni della faggeta di Monte Curcio, Sila Grande (Calabria, Italia meridionale) (Lepidoptera). - Quaderni della Stazione di Ecologia del
Civico Museo di Storia Naturale di Ferrara, 18: 5-19, 2 figg.

Sciarretta A., ZAHM N., 2002 - I Macrolepidotteri dell' "Abetina di Rosello» (Abruzzo) con note faunistiche, biogeografiche ed ecologiche. - Phytophaga, Palermo, XII: $25-42$.

Summerville K.S., Crist T.O., 2008 - Structure and conservation of lepidopteran communities in managed forests of northeastern North America: a review. - The Canadian Entomologist, 140 (4): 475-494.

Summerville K.S., RitTer L.M., CRist T.O., 2004 - Forest moth taxa as indicators of lepidopteran richness and habitat disturbance: a preliminary assessment. Biological Conservation 116: 9-18.

Trematerra P., Scalercio S., Colacci M., 2017 Thaumetopaea hellenica sp.n. and Thaumetopoea mediterranea sp.n. new taxa from Southern Europe (Lepidoptera Notontidae Thaumetopoeinae). - Redia, 100: 3-10. http://dx.doi.org/10.19263/REDIA-100.17.01

Turati E. 1908 - Nuove forme di Lepidotteri. II. - Il Naturalista Siciliano, XX (1907-1908): 1-48.

Walentowski H., Müller-Kroehling S., Bergmeier E., Bernhardt-Römermann M., Gossner M.M., Reif A., Schulze E.D., Bussler H., Strätz C., Adelmann W., 2014 - Faunal diversity of Fagus sylvatica forests: A regional and European perspective. - Annals of Forest Research, 57 (2): 2015-231.

ZiLli A., 1996 - On the little known genus Orectis Lederer, 1857 (Lepidoptera, Noctuidae). - Gortania, Atti del Museo Friulano di Scienze naturali, 16 (1994): 203-212.

ZILLI A., 2014 - Lepidoptera research in areas with high biodiversity potential in Italy. Lepidoptera Italica Vol. 1, Natura Edizioni Scientifiche, Bologna, Italy, 373 pp.

ZILLI A., 2018 - Lepidoptera research in areas with high biodiversity potential in Italy. Lepidoptera Italica Vol. 2, Natura Edizioni Scientifiche, Bologna, Italy, 448 pp.

Zilli A., Maltzeff P., Pinzari M., Raineri V., 2001 - I Lepidotteri della Tenuta Presidenziale di Castelporziano (Lepidoptera). - Bollettino dell'Associazione Romana di Entomologia, 56: 13-48. 